\title{
Early Detection of Periodontitis in Public Health Centres in Malang: An Overview
}

\author{
Hanum Nurma Azuro1, Moch. Yunus ${ }^{2}$, and Rara Warih Gayatri ${ }^{3}$ \\ 'Department of Public Health, Faculty of Sport Science, Universitas Negeri Malang, Malang, \\ Indonesia \\ ${ }^{2}$ Faculty of Sport Science, Universitas Negeri Malang, Malang, Indonesia \\ ${ }^{3}$ Department of Public Health, Faculty of Sport Science, Universitas Negeri Malang, Malang, \\ Indonesia
}

\section{ORCID:}

Rara Warih Gayatri: https://orcid.org/0000-0003-4279-3283

\section{Abstract}

Based on the Basic Health Research (Riskesdas) 2018, the incidence of periodontitis in Indonesia was reported at $74.1 \%$, which makes it one of the most common oral health problems in the country. Overall, 2,759 patients, aged 19-64 years underwent periodontal examinations at the Public Health Centres in Malang between January and

Corresponding Author: Rara Warih Gayatri

rara.warih.fik@um.ac.id

Published: 25 March 2021

Publishing services provided by Knowledge E

(c) Hanum Nurma Azuro et al. This article is distributed under the terms of the Commons Attribution License, which permits unrestricted use and redistribution provided that the original author and source are credited.

Selection and Peer-review under the responsibility of the ISMoPHS 2020 Conference Committee.

\section{G OPEN ACCESS}

September 2019. The present study aimed to determine the description of periodontitis patients at the Public Health Centres, Malang, by conducting an early detection of periodontitis against the risk of the disease. This study used a cross-sectional design and a proportional random sampling technique. In total, 277 respondents visited the Public Health Centres in Malang during the study period. The early detection result is based on the number of questionnaire scores on signs, symptoms, and exposures to risk factors for periodontitis, which are divided into three categories: high, moderate, and low risks. The instrument used in this study is a modification of the previous research instrument by Renatus. The result showed that 58 respondents had moderate (21\%), 4 (1.4\%) had high, and 215 (77.6\%) had low risks of periodontitis. Respondents who had a lower risk of periodontitis were more than the respondents who had high and moderate risks of periodontitis.

Keywords: periodontitis, history of gingivitis, heredity (family history), oral hygiene, history of tobacco use

\section{Introduction}

Periodontitis is an inflammatory condition found in the periodontal [1]. Periodontist disease is the most common disease related to oral health but this disease is often not diagnosed because it does not cause any pain [2]. Currently, periodontitis sufferers in Indonesia reach 74.1\% [3]. According to the basic health research (Riskesdas) data in 2018, East Java Province has the second highest number of people with oral and dental problems after West Java Province [3]. 
Based on the previous study, it is known that the prevalence of visits to periodontal examinations at Public Health Centres in Malang City by the period of JanuarySeptember 2019 reached 2,759 cases aged 19-64 years old category [4]. The periodontal inspection visit data which is reported at Public Health Centres in Malang City Health Department still does not meet the overall data target. This is because not all of the data from Public Health Centres are recorded at the department [4]. However, the data is periodically recorded once in a month [4].

Previous studies on periodontitis described that periodontitis was associated with bleeding in the gums (gingiva) ( $p<0.001$ ) [5]. It is known that bleeding in the gingiva is one of the most common signs and symptoms of periodontitis [5]. Meanwhile, changes in tooth position and the incidence of tooth loss have a significant relationship with periodontitis with $(p<0.001)$ [5]. The questions regarding the use of denture defines a high significance level for the periodontitis incidence $(p<0.001)$ [5]. People who have family history of periodontal shows that they are more likely to have periodontitis with a significance level of $(p=0.042)$ [5]. The questions about tobacco use or smoking history shows a significance level of $(p<0.001)[5]$. As these signs and symptoms increase, a person tends to be positive for periodontitis [5]. Ones with smoking history have a significant level of $(p=0.076)$ [6]. It describes that smokers have a high risk of periodontitis [6]. It could be drawn a conclusion that the lower the quality of oral hygiene in a person, then the greater the risk of periodontal disease [7]. Research on early detection of periodontitis in Public Health Centres Malang was conducted to determine the prevalence or the overview of periodontitis sufferers in Public Health Centres Malang City. The detection is done by measuring the risk of Public Health Centre visitors who are suffering from periodontitis.

\section{Material and Method}

The study employs a quantitative descriptive research by using survey and cross sectional study method. Subjects of the study are the visitors of Janti Public Health Centre, Dinoyo Public Health Centre, Kendalkerep Public Health Centre, Gribig Public Health Centre, and Bareng Public Health Centre which are located in Malang City. They are taken randomly by using cluster random sampling technique. There are 277 people as a sample consisting of 58 people at Puskesmas Janti, 87 people at Bareng Public Health Centre, 48 people at Gribig Public Health Centre, 69 people at Dinoyo Public Health Centre, and 15 at Kendalkerep Public Health Centre. The inclusion criteria of this study are patients who visited Public Health Centre in Malang City by the period 
of January-March 2020, aged 19-64 years old, native of Malang City, and willing to be the research respondents. The exclusion criteria perform in this study are patients who could not participate as research subjects due to physical disabilities or patients who suffering from mental disorders and dementia. The study uses a questionnaire instrument based on signs, symptoms, and risk factors for periodontitis which is a modification from Renatus research to measure the risk of periodontitis on people. The modified instrument is tested for validity, reliability, and diagnostic test.

The researcher conducted the validity test by using expert validity. The questionnaire validation is carried out by public health lecturer who is a dentist, a dentist in the Public Health Centre being researched, and a dentist of a clinic at the State University of Malang. The instrument that the researcher has compiled has a valid $V$ value (content validity coefficient) $0.6-1$ for each question. The questions item are considered to be valid that the validation value must be equal to 0.3 or more [8]. However, the reliability value of the questionnaire instrument compiled by the researcher is 0.6-0.7 for each item. Before conducting the research, the reliability of the instrument was tested to 30 respondents who visited Arjuno Public Health Centre in Malang City. Reliability is a parameter to show that an instrument can be trusted to be used as a data collection tool because the instrument is considered good [9]. The instrument is reliable if the Cronbach Alpha value reaches $>0.6$. It means the questionnaire instrument compiled by the researcher is reliable. Regarding the study, the questionnaire instrument is tested for early detection of periodontitis and a doctor's diagnosis as gold standard. Result of the diagnostic test analysis on the instruments reaches a sensitivity value of (11.11\%) and a specificity value of (76.19\%). The accuracy value of the early detection of periodontitis questionnaire is (56.67\%). In situation where prevalence is low and there is no intention of confirming the diagnosis, the use of a test which has higher specificity value but lower sensitivity is more appropriate [10]. This is because the small number of true positive will be even smaller, and will be obscured by the false positives [10]. The ethical feasibility test in this study was conducted by the Health Research Ethics Commission at the Health Polytechnic of the Ministry of Health Malang with Reg.No.:804 / KEPK-POLKESMA / 2020. The study employs a univariate analysis by dividing the risk of periodontitis into 3 categories which are high risk, moderate risk, and low risk. The categorization is done based on the total score of the questionnaires using strurgess formula. The categories are calculated according to the interval. 


\section{Results}

The following is an overview of early detection of periodontitis risk on community in Public Health Centre Malang. There are 277 respondents which are divided into 3 categories: high risk, moderate risk, and low risk.

TABLE 1: Frequency distribution of early detection result of periodontitis.

\begin{tabular}{|l|c|}
\hline Variable & $\begin{array}{c}\text { Category } \\
\text { Periodontitis }\end{array}$ \\
\hline & High risk \\
Moderate risk \\
\hline \\
Total
\end{tabular}

\begin{tabular}{|c|}
\hline Frequency \\
\hline 4 \\
\hline 58 \\
\hline 215 \\
\hline 277 \\
\hline
\end{tabular}

\begin{tabular}{|c|}
\hline Percentage \\
\hline $1.4 \%$ \\
\hline $21 \%$ \\
\hline $77.6 \%$ \\
\hline $100 \%$ \\
\hline
\end{tabular}

Source: Author's own work.

According to the Table 1, the respondents with a high and moderate risk of periodontitis have a lower prevalence compared to the respondents with a low risk of periodontitis. The respondents with a low risk are 215 people (77.6\%), the respondents with a high risk of periodontitis are 4 people (1.4\%), and the respondents with moderate risk are 58 people (21\%). As stated in the previous discussion, the calculation is based on the questionnaire which has been modified by using Renatus research. The modification is according to the signs and symptoms of periodontitis which are red gingiva, swollen gingiva, gingiva that bleeds easily, gingiva that pulls away from the tooth (recede), tooth loss, wobbly tooth, changes in the shape of the tooth, and uncomfortably feeling in mouth [11]. Moreover, factors that can increase the risk of periodontitis include history of gingivitis, heredity (family history), poor oral hygiene, and tobacco use [11].

Table 2 shows that 1 respondent with high risk of periodontitis (25\%) feels painful when chewing or biting. There are 16 respondents (27.6\%) with moderate risk of periodontitis feels uncomfortable in mouth.

According to the Table 3 above, it describes that the tooth condition of the high risk periodontitis respondents shows symptoms of periodontitis disease. While the tooth signs and symptoms of periodontitis only happen in a few respondents with low risk periodontitis. But more than 100 respondents having a low periodontitis risk of ( $>60 \%)$ claim to have loose tooth. 1 of 4 respondents (25\%) who has a high periodontitis risk using a denture. 20 respondents (34.5\%) who have moderate risk claim to have loose tooth. There are $21-26$ respondents $(<50 \%)$ who have moderate periodontitis risk having loose tooth and loss tooth. 7 respondents (12\%) who have moderate risk claim to have uncomfortable feeling of their denture. 
TABLE 2: Frequency distribution of variable Gingiva condition based on the early detection of periodontitis disease.

\begin{tabular}{|c|c|c|c|c|c|c|c|c|}
\hline \multirow{2}{*}{ Gingiva condition } & \multicolumn{8}{|c|}{ Periodontitis risk } \\
\hline & High & $N(\%)$ & Moderate & $N(\%)$ & Low & $N(\%)$ & Total & $N(\%)$ \\
\hline \multicolumn{9}{|c|}{ Red Gingiva } \\
\hline \multicolumn{9}{|l|}{ Light red gingiva } \\
\hline Yes & 0 & 0 & 14 & 24.1 & 140 & 65.1 & 154 & 55.6 \\
\hline No & 4 & 100 & 44 & 75.9 & 75 & 34.9 & 123 & 44.4 \\
\hline \multicolumn{9}{|c|}{ Changes in colour of gingiva } \\
\hline Yes & 4 & 100 & 48 & 82.8 & 70 & 32.6 & 122 & 44.0 \\
\hline No & 0 & 0 & 10 & 17.2 & 145 & 67.4 & 155 & 56.0 \\
\hline \multicolumn{9}{|l|}{ Red gingiva } \\
\hline Yes & 4 & 100 & 47 & 81 & 68 & 31.6 & 119 & 43.0 \\
\hline No & 0 & 0 & 11 & 19 & 147 & 68.4 & 158 & 57.0 \\
\hline \multicolumn{9}{|c|}{ Swollen Gingiva } \\
\hline \multicolumn{9}{|c|}{ Gingiva that feels enlarged } \\
\hline Yes & 4 & 100 & 45 & 77.6 & 57 & 26.5 & 106 & 38.3 \\
\hline No & 0 & 0 & 13 & 22.4 & 158 & 73.5 & 171 & 61.7 \\
\hline \multicolumn{9}{|c|}{ Gingiva that feels tender when touched } \\
\hline Yes & 3 & 75 & 40 & 69 & 56 & 26 & 99 & 35.7 \\
\hline No & 1 & 25 & 18 & 31 & 159 & 74 & 178 & 64.3 \\
\hline
\end{tabular}

Spitting out blood when brushing your teeth

\begin{tabular}{|l|c|c|c|c|c|c|c|c|}
\hline Yes & 4 & 100 & 44 & 75.9 & 56 & 26 & 104 & 37.5 \\
\hline No & 0 & 0 & 14 & 24.1 & 159 & 74 & 173 & 62.5 \\
\hline
\end{tabular}

Pus between gingiva and tooth

\begin{tabular}{|l|l|l|l|l|l|l|l|l|}
\hline Yes & 2 & 50 & 36 & 62.1 & 96 & 44.7 & 134 & 48.4 \\
\hline No & 2 & 50 & 22 & 37.9 & 119 & 55.3 & 143 & 51.6 \\
\hline
\end{tabular}

Gingiva that feels painful when used to chew or bite

\begin{tabular}{|l|l|l|l|l|l|l|l|l|}
\hline Yes & 1 & 25 & 42 & 72.4 & 77 & 35.8 & 120 & 43.3 \\
\hline No & 3 & 75 & 16 & 27.6 & 138 & 64.2 & 158 & 57.0 \\
\hline
\end{tabular}

Uncomfortable feeling in mouth

A change in the way your teeth fit together when you bite

\begin{tabular}{|c|c|c|c|c|c|c|c|c|}
\hline Yes & 1 & 75 & 16 & 27.6 & 6 & 2.8 & 23 & 8.3 \\
\hline No & 3 & 25 & 42 & 72.4 & 209 & 97.2 & 254 & 91.7 \\
\hline \multicolumn{9}{|c|}{ Gingiva loose } \\
\hline \multicolumn{9}{|c|}{ Gingiva recede } \\
\hline Yes & 4 & 100 & 32 & 55.2 & 7 & 3.3 & 43 & 15.5 \\
\hline No & 0 & 0 & 26 & 44.8 & 208 & 96.7 & 234 & 84.5 \\
\hline
\end{tabular}

Source: Author's own work. 
TABLE 3: Frequency distribution of variable tooth condition according to the early detection of periodontitis disease.

\begin{tabular}{|c|c|c|c|c|c|c|c|c|}
\hline \multirow[t]{2}{*}{ Tooth condition } & \multicolumn{8}{|c|}{ Periodontitis risk } \\
\hline & High & $N(\%)$ & Moderate & $N(\%)$ & Low & $N(\%)$ & Total & $N(\%)$ \\
\hline \multicolumn{9}{|c|}{ Tooth that looks longer } \\
\hline \multicolumn{9}{|c|}{ Teeth looks longer until reach the tip of the root } \\
\hline Yes & 4 & 100 & 29 & 50 & 9 & 4.2 & 42 & 15.2 \\
\hline No & 0 & 0 & 29 & 50 & 206 & 95.8 & 235 & 84.8 \\
\hline \multicolumn{9}{|c|}{ Change in tooth position } \\
\hline \multicolumn{9}{|l|}{ Teeth shifting } \\
\hline Yes & 4 & 100 & 20 & 34.5 & 16 & 7.4 & 40 & 14.4 \\
\hline No & 0 & 0 & 38 & 65.5 & 199 & 92.6 & 237 & 85.6 \\
\hline \multicolumn{9}{|c|}{ There are significant space among the teeth } \\
\hline \multicolumn{9}{|l|}{ Teeth loose } \\
\hline Yes & 3 & 75 & 49 & 84.5 & 135 & 62.8 & 187 & 67.5 \\
\hline No & 1 & 25 & 9 & 14.5 & 80 & 37.2 & 90 & 32.5 \\
\hline \multicolumn{9}{|c|}{ Food often stuck among the teeth } \\
\hline Yes & 3 & 75 & 53 & 91.4 & 144 & 67 & 200 & 72.2 \\
\hline No & 1 & 25 & 5 & 8.6 & 71 & 33 & 77 & 27.8 \\
\hline \multicolumn{9}{|c|}{ Wobbly teeth } \\
\hline \multicolumn{9}{|c|}{ There is a wobbly teeth } \\
\hline Yes & 4 & 100 & 26 & 44.8 & 39 & 18.1 & 69 & 24.9 \\
\hline No & 0 & 0 & 32 & 55.2 & 176 & 81.9 & 208 & 75.1 \\
\hline \multicolumn{9}{|c|}{ Wobbly teeth due to swollen gingiva } \\
\hline Yes & 3 & 75 & 21 & 36.2 & 14 & 6.5 & 38 & 13.7 \\
\hline No & 1 & 25 & 37 & 63.8 & 201 & 93.5 & 239 & 86.3 \\
\hline \multicolumn{9}{|c|}{ Tooth Loss } \\
\hline \multicolumn{9}{|c|}{ There is tooth loss due to swollen gingiva } \\
\hline Yes & 3 & 75 & 22 & 37.9 & 28 & 13 & 53 & 19.1 \\
\hline No & 1 & 25 & 36 & 62.1 & 187 & 97 & 224 & 80.9 \\
\hline \multicolumn{9}{|l|}{ Using denture } \\
\hline Yes & 1 & 25 & 12 & 20.7 & 22 & 10.2 & 35 & 12.6 \\
\hline No & 3 & 75 & 46 & 79.3 & 193 & 89.8 & 242 & 87.4 \\
\hline \multicolumn{9}{|c|}{ Feels uncomfortable when using a denture } \\
\hline Yes & 0 & 0 & 7 & 12.1 & 8 & 8 & 15 & 5.4 \\
\hline No & 4 & 100 & 51 & 87.9 & 207 & 90.2 & 262 & 94.6 \\
\hline
\end{tabular}

Source: Author's own work. 
TABLE 4: Frequency distribution of variable Gingivitis history according to the early detection of periodontitis disease.

\begin{tabular}{|c|c|c|c|c|c|c|c|c|}
\hline \multirow[t]{2}{*}{ Gingivitis history } & \multicolumn{8}{|c|}{ Periodontitis risk } \\
\hline & High & $\mathbf{N}(\%)$ & Moderate & $\mathbf{N}(\%)$ & Low & $N(\%)$ & Total & $N(\%)$ \\
\hline \multicolumn{9}{|c|}{ Have an experience of inflammation on gingiva (gingivitis) } \\
\hline Yes & 3 & 75 & 39 & 67.2 & 73 & 34 & 115 & 41.5 \\
\hline No & 1 & 25 & 19 & 32.8 & 142 & 66 & 162 & 58.5 \\
\hline \multicolumn{9}{|c|}{ Have an experience of gingivitis examination } \\
\hline Yes & 3 & 75 & 28 & 48.3 & 36 & 16.7 & 67 & 24.2 \\
\hline No & 1 & 25 & 30 & 51.7 & 179 & 83.3 & 210 & 75.8 \\
\hline \multicolumn{9}{|c|}{ Have an experience of gingivitis treatment } \\
\hline Yes & 3 & 75 & 28 & 48.3 & 32 & 14.9 & 63 & 22.7 \\
\hline No & 1 & 25 & 30 & 51.7 & 183 & 85.1 & 214 & 77.3 \\
\hline \multicolumn{9}{|c|}{ Have an experience of gingivitis and loss tooth } \\
\hline Yes & 2 & 50 & 15 & 25.9 & 13 & 6 & 30 & 10.8 \\
\hline No & 2 & 50 & 43 & 74.1 & 202 & 94 & 247 & 89.2 \\
\hline
\end{tabular}

Source: Author's own work.

Table 4 describes that there are 2 respondents (50\%) with high risk of periodontitis are likely to have advanced gingivitis. Most of them have undergone examination and treatment of gingivitis with the total of 3 respondents (75\%). While there are 39 respondents (67.2\%) who experience gingivitis with moderate risk of periodontitis. The increasing of periodontitis risk is in line with history of gingivitis experienced by the respondents.

TABLE 5: Frequency distribution variable family history according to the early detection of periodontitis disease.

\begin{tabular}{|c|c|c|c|c|c|c|c|c|}
\hline \multirow[t]{2}{*}{ Family history } & \multicolumn{8}{|c|}{ Periodontitis Risk } \\
\hline & High & $\mathbf{N}(\%)$ & Moderate & $N(\%)$ & Low & $N(\%)$ & Total & $N(\%)$ \\
\hline \multicolumn{9}{|c|}{ There are family members who experience periodontal disease } \\
\hline Yes & 1 & 25 & 22 & 37.9 & 37 & 8.6 & 60 & 21.6 \\
\hline No & 3 & 75 & 36 & 62.1 & 178 & 91.4 & 217 & 78.4 \\
\hline \multicolumn{9}{|c|}{ There are family members who have had periodontal disease treatment } \\
\hline Yes & 1 & 25 & 18 & 31 & 26 & 5.2 & 45 & 16.2 \\
\hline No & 3 & 75 & 40 & 69 & 189 & 94.8 & 232 & 83.8 \\
\hline
\end{tabular}

Source: Author's own work.

Table 5 above shows that there are two questions on variable family history. From the first question, it is known that the respondents with family history of periodontal disease are 60 respondents (21.6\%). While from the second question, it is known that the respondents with family history of periodontal disease treatment are 45 respondents (16.2\%). According to the table 5 , the moderate risk of periodontitis are they who have 
family members who experienced periodontal issue with the total of 22 respondents (37.9\%). The family members are father, mother, grandfather, grandmother, and child.

TABLE 6: Frequency distribution of variable oral hygiene history according to the early detection of periodontitis disease.

\begin{tabular}{|c|c|c|c|c|c|c|c|c|}
\hline \multirow{2}{*}{$\begin{array}{l}\text { History of oral } \\
\text { hygiene }\end{array}$} & \multicolumn{8}{|c|}{ Periodontitis risk } \\
\hline & High & $N(\%)$ & Moderate & $\mathbf{N}(\%)$ & Low & $N(\%)$ & Total & $N(\%)$ \\
\hline \multicolumn{9}{|c|}{ Cleaning the outer surfaces of the top and bottom teeth with up and down strokes } \\
\hline Yes & 2 & 50 & 38 & 65.5 & 162 & 75.3 & 202 & 72.9 \\
\hline No & 2 & 50 & 20 & 34.5 & 53 & 24.7 & 75 & 27.1 \\
\hline
\end{tabular}

Cleaning the inside surfaces of the top and bottom front teeth with back and forth motions repeatedly

\begin{tabular}{|l|c|c|c|c|c|c|c|c|}
\hline Yes & 4 & 100 & 49 & 84.5 & 187 & 87 & 240 & 86.6 \\
\hline No & 0 & 0 & 9 & 15.5 & 28 & 13 & 37 & 13.4 \\
\hline
\end{tabular}

Cleaning the outer surfaces of the top and bottom back teeth with back and forth motions repeatedly

\begin{tabular}{|l|c|c|c|c|c|c|c|c|}
\hline Yes & 4 & 100 & 50 & 86.2 & 197 & 91.6 & 251 & 90.6 \\
\hline No & 0 & 0 & 8 & 13.8 & 18 & 8.4 & 26 & 9.4 \\
\hline
\end{tabular}

Cleaning the inside surfaces of the top and bottom back teeth with back and forth motions repeatedly

\begin{tabular}{|c|c|c|c|c|c|c|c|c|c|}
\hline Yes & 4 & 100 & 48 & 82.8 & 197 & 91.6 & 249 & 89.9 \\
\hline No & 0 & 0 & 10 & 17.2 & 18 & 8.4 & 28 & 10.1 \\
\hline
\end{tabular}

Brushing teeth twice or more in a day

\begin{tabular}{|l|c|c|c|c|c|c|c|c|c|}
\hline Yes & 3 & 75 & 53 & 91.4 & 200 & 93 & 256 & 92.4 \\
\hline No & 1 & 25 & 5 & 8.6 & 15 & 7 & 21 & 7.6 \\
\hline
\end{tabular}

Going to the dentist for a regular check-up (at least every 6 months)

\begin{tabular}{|c|c|c|c|c|c|c|c|c|}
\hline Yes & 0 & 0 & 10 & 17.2 & 28 & 13 & 38 & 13.7 \\
\hline No & 4 & 100 & 48 & 82.8 & 187 & 87 & 239 & 86.3 \\
\hline \multicolumn{9}{|c|}{ Using moderate bristle toothbrush } \\
\hline Yes & 2 & 50 & 51 & 87.9 & 197 & 91.6 & 250 & 90.3 \\
\hline No & 2 & 50 & 7 & 12.1 & 18 & 8.4 & 27 & 9.7 \\
\hline \multicolumn{9}{|c|}{ Using toothpaste with fluoride } \\
\hline Yes & 3 & 75 & 55 & 94.8 & 203 & 94.4 & 261 & 94.2 \\
\hline No & 1 & 25 & 3 & 5.2 & 12 & 5.6 & 16 & 6.8 \\
\hline \multicolumn{9}{|c|}{ Using toothpick } \\
\hline Yes & 4 & 100 & 32 & 55.2 & 106 & 50.7 & 142 & 51.3 \\
\hline No & 0 & 0 & 26 & 44.8 & 109 & 49.3 & 135 & 48.7 \\
\hline \multicolumn{9}{|c|}{ Using dental floss } \\
\hline Yes & 0 & 0 & 4 & 6.9 & 9 & 4.2 & 13 & 4.7 \\
\hline No & 4 & 100 & 54 & 93.1 & 206 & 95.8 & 264 & 95.3 \\
\hline \multicolumn{9}{|c|}{ Brushing teeth before going to bed } \\
\hline Yes & 2 & 50 & 41 & 70.7 & 149 & 69.3 & 191 & 69.3 \\
\hline No & 2 & 50 & 17 & 29.3 & 66 & 30.7 & 86 & 30.7 \\
\hline
\end{tabular}

Source: Author's own work. 
Based on table 6 , it is known that $>100$ respondents ( $>85 \%$ ) at low risk of periodontitis are the ones who brush their teeth properly and correctly. The respondents at moderate risk of periodontitis are they who go to the dentist for a regular check-up (at least every 6 months) which are 10 respondents (17.2\%). There are 13 respondents (4.7\%) using dental floss. The respondents at high risk of periodontitis are they who commonly use toothpick to clean their teeth which are 4 respondents (100\%).

TABLE 7: Frequency distribution of variable history of tobacco use according to the early detection of periodontitis disease.

\begin{tabular}{|c|c|c|c|c|c|c|c|c|}
\hline \multirow{2}{*}{$\begin{array}{l}\text { History of } \\
\text { tobacco use }\end{array}$} & \multicolumn{8}{|c|}{ Periodontitis risk } \\
\hline & High & $N(\%)$ & Moderate & $N(\%)$ & Low & $N(\%)$ & Total & $N(\%)$ \\
\hline \multicolumn{9}{|l|}{ A smoker } \\
\hline Yes & 2 & 50 & 10 & 8.7 & 20 & 9.3 & 32 & 11.6 \\
\hline No & 2 & 50 & 48 & 91.3 & 195 & 90.7 & 245 & 88.4 \\
\hline \multicolumn{9}{|c|}{ The one who has been a smoker before } \\
\hline Yes & 3 & 75 & 10 & 8.7 & 19 & 8.8 & 32 & 11.6 \\
\hline No & 1 & 25 & 58 & 91.3 & 196 & 91.2 & 245 & 88.4 \\
\hline \multicolumn{9}{|c|}{ Smoke 10 or more cigarettes a day } \\
\hline Yes & 1 & 25 & 8 & 4 & 9 & 4.2 & 18 & 6.5 \\
\hline No & 3 & 75 & 50 & 96 & 206 & 95.8 & 259 & 93.5 \\
\hline \multicolumn{9}{|c|}{ Still smoking after experiencing periodontal disease } \\
\hline Yes & 2 & 50 & 6 & 1.7 & 3 & 1.4 & 11 & 4 \\
\hline No & 2 & 50 & 52 & 98.3 & 212 & 98.6 & 266 & 96 \\
\hline
\end{tabular}

Source: Author's own work

Table 7 shows that there are 32 respondents (11.6\%) who smoke or have been a smoker. There are 18 respondents (6.5\%) who smoke 10 or more cigarettes a day. As many as 11 respondents (4\%) still smoke after experiencing periodontal disease. As many as 2 respondents (31\%) at high risk of periodontitis are smoker. 1 respondent (25\%) with high risk of periodontitis smoke 10 or more cigarettes in a day. There are 2 respondents (50\%) at high risk of periodontitis still smoke after experiencing periodontal disease.

\section{Discussion}

\subsection{Early detection result of periodontitis}

The respondents with a high and moderate risk of periodontitis have a lower prevalence compared to the respondents with a low risk of periodontitis. Prevalence of aggressive periodontitis sufferers in Faculty of Dentistry at Padjajaran University of Bandung is (3.13\%) from the total of 415 samples [12]. The research is conducted using questionnaire 
based on the age, gender, profession, background of study, the subjects knowledge regarding periodontal disease, and the factors of the disease [12]. There are (31\%) or 124 people with chronic periodontitis in Bandung [13]. The research on prevalence of chronic periodontitis in Bandung is conducted by using instrument from Community Periodontal Index of Treatment Needs (CPITN) [13]. Patients with periodontitis in Magelang Regency reach (37.8\%) from 90 people as the research subjects [14]. The instrument used is a questionnaire which is arranged by the researchers [14]. The prevalence score of high and moderate risk of periodontitis in Public Health Centre Malang City is lower compared to the prevalence score from the previous studies. It is because there are differences criteria among the respondents as samples and the variables as measuring instruments.

\subsection{Gingiva condition based on the early detection of periodontitis}

The condition of gingiva that easily bleeds and gingiva recede increases as well as the increasing of periodontitis risk on the respondents. It shows that the bleeding and the receding gingival are the signs that the respondents have periodontitis $[5,6]$. The result regarding the question of swollen gingival is as well as the increasing of periodontitis risk by the respondents. The previous study also showed that the swollen gngiva relates to periodontitis ( $p<0.05$ ), it is concluded that the swollen gingiva is a sign of periodontal disease. [15]. The sub-variable research result of sore gingiva does not meet the expectation because only a few of the high risk periodontitis respondents that feels the symptom. Measure of belief regarding the gingiva that feels painful when chewing or biting to periodontitis disease is $(\mathrm{MB}=0.85)$, the score is measured by an Expert named drg. Lesningatie Gideon [16]. It could happen because the high risk periodontitis respondents more likely have tooth loss, so they chew or bite by using the normal teeth. Moreover, the sub-variable result of uncomfortable feeling in the mouth ia also does not meet the expectation. The certain factors regarding the uncomfortably feeling in the mouth to periodontitis is $(C F=1)$, the score is measured by an expert named drg. Maya Fitria SP [17]. It could happen because the differences of the respondents assumption to the meaning of the questions they received.

\subsection{Tooth condition according to the early detection of periodon- titis}

The loose tooth does not have a significant relationship to periodontitis $(p=0.328)[6]$. The question regarding the loose tooth shows invalid results to detect periodontitis 
disease [18]. The question regarding loss tooth is not in line with the increasing of periodontitis risk. The previous study claimed that loss tooth has $(p<0.001)$ meaning that loss tooth has a significant relationship with periodontitis [5]. It could happen because the moderate periodontitis risk respondents still on the first stage of the disease. The question result regarding the denture is contrary to the previous study, where the denture condition has a significant relationship with periodontitis $(p<0.001)$ [5]. Percentage of denture user in this research is lower than the user of the previous study, where the users are (54\%) from the total population [5]. This is reinforced by other studies that had fewer denture users (32\%) of the total population, the use of dentures in fewer studies showed an insignificant relationship with the incidence of periodontitis. [19]. Respondents with low risk of periodontitis are known to have a high enough number of sub-variables on the loose teeth. Overcrowded teeth are more at risk of suffering from periodontitis than the loose teeth [20]. This is probably occurred because the respondents who have loose or crowded teeth have a lower chance of cleaning the entire tooth surface, when compared to respondents who have loose teeth [21].

\subsection{Gingivitis history according to the early detection of periodon- titis}

The increasing of periodontitis risk is in line with history of gingivitis experienced by the respondents. The gingiva that had previously inflamed were (70\%) more likely to develop periodontitis than those who had no previous gingiva inflammation [22]. Gingivitis that is continuously allowed will have the potential to become a periodontitis disease. Gingivitis can cause tooth loss [23]. Gingivitis is one of the signs and symptoms of periodontitis [11]. The build-up of plaque on the teeth can cause inflammation of the gingiva and is called gingivitis [11]. Gingivitis can turn into periodontitis if someone who has gingivitis does not immediately get treatment. Gingivitis that is left unchecked will get worse and can cause periodontitis [11].

\subsection{Family history according to the early detection of periodontitis}

The periodontitis sufferers have a significant relationship with the history of family members who had experience or experiencing periodontitis with $(p<0.05)$ [24]. Periodontitis has a significant relationship with the family members with $(p=0.042)$ [5]. Result of the questions regarding history of family members does not meet the expectation. It is 
because the majority of the respondents do not know their family members who had experienced periodontal disease. They tend to know their family members to the extent of a common toothache. Information that is less detailed on dental disease suffered by families causes the percentage of family history or heredity does not match the expectation.

\subsection{Oral hygiene history according to the early detection of peri- odontitis}

Oral hygiene has a significant relationship with periodontitis $(p<0.05)$ [7]. The adherence to a regular check-up to a dentist shows a significant relationship with periodontitis $(p<0.001)$ [5]. Based on the previous study, there are (54\%) respondents who commonly use toothpick experience a weakening of the attachment of the root to the gingival and leads to periodontitis [25].

\subsection{History of tobacco use according to the early detection of peri- odontitis}

Smoker has a significant relationship with periodontitis disease $(p<0.05)$ [24]. The results showed that 1 in 4 respondents at high risk of periodontitis smoked 10 or more cigarettes per day which is not in accordance with the previous studies. The smoking behaviour of 10 or more cigarettes in a day, based on the previous studies, had a significant relationship with periodontitis $(p<0.001)$ [5]. It could possibly happen because the respondents at high risk of periodontitis who smoke less than 10 cigarettes per day have other contributing factors for suffering from periodontitis.

\section{Conclusion}

The early detection of periodontitis conducted in Public Health Centre Malang City results 215 respondents (77.6\%) have a low risk of periodontitis. There are 58 respondents (21\%) with moderate risk of periodontitis. As many as 4 respondents (1.4\%) have a high risk of periodontitis. The respondents at low risk of periodontitis are more than the respondents at high and moderate risk of periodontitis. Regarding the signs and symptoms of periodontitis, it is known that only 1 respondent (25\%) at high risk of periodontitis who is painful when chewing or biting. In addition, the uncomfortable feeling in mouth is experienced by 16 respondents (27.6\%) at moderate risk of periodontitis. Regarding the 
tooth condition, it is known that braces is experienced by more than 100 respondents (>60\%) at low risk of periodontitis. Tooth change is experienced by 20 respondents (34.5\%) at moderate risk of periodontitis. Moreover, signs and symptoms of tooth loose is experienced by $21-26$ respondents $(<50 \%)$ at moderate risk of periodontitis. Gingivitis is experienced by 2 respondents (50\%) at high risk of periodontitis while there are 39 respondents (67.2\%) who experience gingivitis at moderate risk of periodontitis. The family history of periodontal disease is 22 respondents $(37.9 \%)$ at moderate risk of periodontitis. Regarding the oral hygiene, it is known that going to the dentist for a regular check-up (at least once in 6 months) is done by 10 respondents (17.2\%) with moderate risk of periodontitis. Toothpick is used by 4 respondents (100\%) at high risk of periodontitis. Regarding the tobacco use, it is known that there are 32 respondents (11.6\%) who are smoker or experienced smoking while 2 respondents (50\%) at high risk of periodontitis still smoke after experiencing periodontal disease.

\section{Acknowledgment}

We would like to thank the lecturers of Universitas Negeri Malang who help us for validating the instruments and the research participants in the data collection. Also, we would like to express our greatest gratitude to Universitas Negeri Malang for funding the study.

\section{Conflict of Interest}

The author declare that they have no conflict of interest

\section{References}

[1] Kiswaluyo, K. (2013). Perawatan Periodontitis pada Puskesmas Sumbersari, Puskesmas Wuluhan dan RS Bondowoso. Stomatognatic Jurnal Kesehatan Gigi Universitas Negeri Jember, vol. 10, issue 3, pp. 115-20.

[2] Susilawati, I. D. A. (2011). Periodontal Infection is a "Silent Killer." Stomatognatic Jurnal Kesehatan Gigi Universitas Negeri Jember, vol. 8, issue 1, pp. 21-6.

[3] Riset Kesehatan Dasar. (2018). Laporan Nasional. Jakarta: Kemenkes RI.

[4] Dinas Kesehatan Kota Malang. (2019). Prevalensi Penyakit Periodontal di Kota Malang Tahun 2019. Malang: Dinas Kesehatan Kota Malang. 
[5] Renatus, A. (2016). Evaluation of a New Self- Reported Tool for Periodontitis Screening. Journal of Clinical and Diagnostic Research. Issue 6. 109-110.

[6] Yamamoto, T., et al. (2009). Validity of a Questionnaire for Periodontitis Screening of Japanese Employees. Journal of Occupational Health, vol. 51, issue 2, pp. 137-143.

[7] Cengiz, M. I., Zengin, B. and Köktürk, F. (2018). Prevalence of Periodontal Disease among Mine Workers of Zonguldak, Kozlu District, Turkey: A Cross-sectional Study. BMC Public Health.,vol. 18, issue 361, pp. 1-7.

[8] Sugiyono. (2016). Metode Penelitian Kuantitatif, Kualitatif dan R\&D. Bandung: Alfabeta.

[9] Arikunto, S. (2013). Prosedur Penelitian: Suatu Pendekatan Praktik. Jakarta: Rineka Cipta.

[10] Ismah, Z. (2018). Bahan Ajar Dasar Epidemiologi. Medan: Fakultas Kesehatan Masyarakat.

[11] Pertiwiningsih, B. I. (2016). Kesehatan Masyarakat Kesehatan Gigi dan Mulut. Surakarta: Borobudur Inspira Nusantara.

[12] Nariratih, D., Rusjanti, J. and Susanto, A. (2011). Prevalence and Characteristics of Aggressive Periodontitis. Padjadjaran Journal of Dentistry, vol. 23, issue 2, pp. 97104.

[13] Susanto, A., et al. (2018). The Prevalence of Chronic Periodontitis in the City of Bandung, Indonesia: A Cross Sectional Study. International Journal of Medical Science and Clinical Invention, vol. 5, issue 7, pp. 3914-6.

[14] Sugiarti, T. and Santik, Y. D. P. (2017). Kejadian Periodontitis di Kabupaten Magelang. HIGEIA (Journal of Public Health Research and Development), vol. 1, issue 4, pp. 97-108.

[15] Kabali, T. M. and Mumghamba, E. G. (2018). Knowledge of Periodontal Diseases, Oral Hygiene Practices, and Self-Reported Periodontal Problems among Pregnant Women and Postnatal Mothers Attending Reproductive and Child Health Clinics in Rural Zambia. International Journal of Dentistry, issue 1, pp. 1-9.

[16] Valentine, H. M., Nasution, H. and Sastypratiwi, H. (2015). Perancangan Sistem Pakar Diagnosis Awal Penyakit Gigi dan Mulut Menggunakan Metode Dempster Shafer. Justin (Jurnal Sistem dan Teknologi Informasi), vol. 3, issue 3, pp. 291-7.

[17] Suryani, P. N. D. (2019). Sistem Pakar untuk Mendiagnosis Penyakit Gigi dan Mulut (Thesis, Universitas Islam Indonesia, 2019).

[18] Ramos, R. Q., Bastos, J. L. and Peres, M. A. (2016). Validity of Periodontitis Screening Questions in a Brazilian Adult Population-Based Study. Brazilian Oral Research, vol. 30, issue 1, pp. 1-5. 
[19] Lorentz, T. C. M., et al. (2010). Tooth Loss in Individuals under Periodontal Maintenance Therapy: Prospective Study. Brazilian Oral Research, vol. 24, issue 2, pp. 231-7.

[20] Nataris, A. S. and Santik, Y. D. P. (2017). Faktor Kejadian Gingivitis pada Ibu Hamil. HIGEIA (Journal of Public Health Research and Development), vol. 1, issue 3, pp. 117-8.

[21] Wahyuningsih, S., Hardjono, S. and Suparwitri, S. (2014). Perawatan Maloklusi Angle Klas I dengan Gigi Depan Crowding Berat dan Cross Bite Menggunakan Teknik Begg pada Pasien dengan Kebersihan Mulut Buruk. Majalah Kedokteran Gigi Indonesia, vol. 21, issue 2, pp. 204-11.

[22] Lang, N. P., Schätzle, M. A. and Löe, H. (2009). Gingivitis as a Risk Factor in Periodontal Disease. Journal of Clinical Periodontology, vol. 36, issue 10, pp. $3-$ 8.

[23] Nagarajan, R., et al. (2015). Patient-Specific Variations in Biomarkers across Gingivitis and Periodontitis. PLOS ONE, vol. 10, issue 9, pp. 1-15.

[24] Ziukaite, L., et al. (2017). Family History of Periodontal Disease and Prevalence of Smoking Status among Adult Periodontitis Patients: A Cross-Sectional Study. International Journal of Dental Hygiene, vol. 15, issue 4, pp. e28-e34.

[25] Hamid, E. M. (2017). Pengaruh Penggunaan Tusuk Gigi Berpenampang Bulat terhadap Kedalaman Perlekatan Klinis pada Gingiva di Desa Bontona Saluk. Media Kesehatan Gigi, vol. 16, issue 1, pp. 27-31. 